\title{
Objective lameness assessment in horses used for equine-assisted therapy in Rio Grande do Sul State, Brazil
}

\author{
Patricia Maurer Taschetto ${ }^{1^{*}}$ (i) Marcos da Silva Azevedo ${ }^{1}$ (i) Ana Paula da Costa Rodrigues ${ }^{1}$ (i) \\ Luíza Gonçalves Martini $^{1}$ (D) Daniélle Fernandes Cosentino Siqueira ${ }^{1}$ (D) \\ Andressa Schunemann Bernardes ${ }^{1}$ (i) Bruna Martins Parodes ${ }^{1}$ (i)
}

${ }^{1}$ Departamento de Medicina Veterinária, Setor de Clínica e Cirurgia de Grandes Animais, Universidade Federal do Pampa (UNIPAMPA), 97501-970, Uruguaiana, RS, Brasil. E-mail: patriciataschetto@gmail.com. *Corresponding author.

ABSTRACT: Equine-assisted therapy is a method used since ancient times to rehabilitate individuals. The biomechanics provided by horses and the friction between their back and the riders'saddle generate impulses that are transmitted to riders' central nervous system; thus, these horses must be healthy enough to enable the desired therapeutic effect. The aim of the current study is to investigate lameness prevalence and intensity in equine-assisted therapy horses in Rio Grande do Sul State. The adopted methodology consisted of the objective evaluation of lameness based on Lameness Locator ${ }^{\circledR}$ wireless inertial sensors, which were placed in the 21 horses assessed in six equestrian centers in Rio Grande do Sul State. Results have shown that 90.1\% of the assessed horses presented lameness in the hind (54.2\%) and forelimbs (45.8\%), as well as that $72 \%$ of them with presented mild lameness degree. This outcome has evidenced the need, and significance, of assessing these horses' locomotor system. To support effective therapy and protect equine welfare, it is essential that veterinarians should regularly monitor these animals in order to treat and prevent disease. Even subtle lameness can influence the generated stimuli; thus, it is an important factor to be taken into consideration when selecting equine-assisted therapy.

Key words: horse riding, inertial sensors, Lameness Locator ${ }^{T M}$, animal assisted therapy.

Avaliação objetiva da claudicação em cavalos de equoterapia no Rio Grande do Sul, Brasil

RESUMO: A equoterapia é um método de terapia, utilizada para reabilitação do praticante desde a antiguidade. A biomecânica proporcionada pelo cavalo e o atrito entre o dorso do cavalo e a sela do praticante geram impulsos que são transmitidos ao sistema nervoso central do mesmo, por isso a importância desse cavalo estar em condições aptas para promover o efeito terapêutico desejado. Nosso objetivo foi identificar a prevalência e intensidade da claudicação em equinos de equoterapia no estado do Rio Grande do Sul. A metodologia utilizada foi a avaliação objetiva da claudicação com base na utilização de sensores inerciais sem fio Lameness Locator ${ }^{\mathbb{B}}$ em seis centros equestres do Rio Grande do Sul, totalizando 21 equinos avaliados. Foi constatado que 90,1\% dos equinos avaliados apresentavam claudicação, $54,2 \%$ do membro pélvico e 45,8\% do membro torácico, quanto a intensidade $72 \%$ foram leves. A partir desse resultado, verifica-se a necessidade e a importância da avaliação no sistema locomotor destes animais. Para uma terapia eficaz e proteger o bem-estar dos equinos, é essencial o acompanhamento periódico por um médico veterinário para tratamento e prevenção de afecções. Claudicações, mesmo sutis, podem interferir nos estímulos gerados, sendo um importante fator de escolha do cavalo apto para a equoterapia.

Palavras-chave: equitação, sensores inerciais, Lameness Locator ${ }^{T M}$ terapia assistida por animal.

\section{INTRODUCTION}

Equine-assisted therapy is a technique that uses horses in an interdisciplinary approach across the health, education and horse-riding fields. It enables the rehabilitation of patients with special needs or disabilities, as well as of elderly individuals, among others, since it brings physical and mental benefits to them (TOIGO et al., 2008; SILVEIRA \& WIBELINGER, 2011). The technique, which was used in Europe, was introduced in Brazil in 1989. It enables individuals to interact with horses since their first contact, as well as to ride and handle them. Besides enabling new socialization forms, this activity helps individuals to improve their self-confidence and self-esteem. Activities held on horseback allow the treatment of overall body muscles in a natural manner, since they enable modulating and improving individuals' muscle tone, posture, rhythm, balance and coordination. In addition, stretching exercises help improving social integration and make individuals more independent 
to perform daily tasks (PEREIRA et al., 2020; PFEIFER et al., 2012).

Equine-assisted therapies performed with autistic children have shown that after a week of sessions, they have improved their development, specifically communication, perceptive, emotional and motor adjustment (HAMEURY et al., 2010). WHITE-LEWIS et al. (2017) carried out a systematic review of the results obtained with the practice of assisted therapy with horses, noting that balance, spasticity, gait and rhythm were improved with the intervention, improving the quality of life. LEMKE et al. (2014) demonstrated that the practice helped to maintain strength, posture, control and range of motion in children with Spinal Muscular Atrophy.

Horses, most commonly, present four natural gait types, namely: walk, trot, canter and gallop (BARREY, 2013). Equine-assisted therapy sessions adopt the walk gait, since trot and gallop are gaits with suspension phase and require individuals to have greater balance (PFEIFER et al., 2012). The movement produced by horses' walk gait generates stimuli that boost the central nervous system of individuals with impaired balance, motor coordination and muscle tone. The three-dimensional movement generated by the connection between the animals' back and the riders' saddle is fundamental for equine-assisted therapy, since it stimulates individuals' central nervous system (ANDRADE \& CUNHA, 2014). The longer the stride length, the greater the horse's back movement, which enables better muscle use of the practitioner due to wide movement oscillation (UZUN, 2005).

According to LOJEK et al. (2015) horse selection for equine-assisted therapy is based on several features, with emphasis on animal conformation. Animals presenting conformation defects are more likely to have lameness; therefore, their locomotion dynamics is often compromised (BAXTER, 2011b). Assumingly, lameness can affect animals' strides; consequently, it can affect the stimulus they generate in individuals.

The aim of the current study was to objectively evaluate lameness prevalence and intensity in horses used for equine-assisted therapy in different equestrian centers in Rio Grande do Sul State, Brazil.

\section{MATERIALS AND METHODS}

\section{Animals}

The present study assessed 21 horses (one pure and 20 crossbreed Criolo horses), 11 mares and 10 geldings (mean weight of $415 \mathrm{~kg} \pm 35.8 \mathrm{~kg}$ and mean age of 16.5 years \pm 4 years). They were evaluated at six equestrian centers in Rio Grande do Sul State, in the following counties: São Gabriel - four animals (Group A); Santa Maria - animals from two different equestrian centers, the first center provided four animals (Group B) and the second one provided two animals (Group F); Santo Ângelo - four animals (Group C); São Luiz Gonzaga - four animals (Group D); and Itaqui - three animals (Group E). The animals' normal working protocol consisted of therapy center sessions held twice a week (C, D and E), three times a week (A and F) and four times a week (B). The data collections for this experiment were conducted on days when the animals were not at work, usually on Saturdays and Sundays at the riding therapy centers.

Data collection was initially based on general clinical examination, which comprised assessing animals' heart and respiratory rates, mucosal color, capillary refill time and body temperature. The second data collection started after any change in baseline parameters was ruled out; it was carried out through specific examination of animals' locomotor system and through the objective lameness assessment based on the wireless inertial sensor system (Lameness Locator ${ }^{\circledR}$ ). The inclusion criteria for horses in the study were: they were participating in therapy center and clinically healthy, without clinical evidence of ataxia.

\section{Objective lameness assessment}

After the conduction of the first part of the specific examination of the locomotor system, which comprised anamnesis, inspection and palpation, animals were equipped with inertial wireless sensors $\left(\right.$ Lameness Locator $^{\mathbb{R}}$ ) to enable the in-movement examination and the flexion tests. The Equinosis Q with Lameness Locator $^{\circledR}$ is a portable system that allows the veterinarian to objectively assess lameness with non-invasive inertial sensors. These inertial sensors and algorithms of the Lameness Locator compare an asymmetry of movement of two trunk entrants (right and left) in the differences in minimum and maximum height produced by the head and pelvis (in millimeters) during the strides (EQUINOSIS, 2019).

Animals' instrumentation, as well as data collection and analysis, were carried out as recommended by KEEGAN et al. (2011), being placed by the same person in all evaluated horses. Each horse had an accelerometer attached to the dorsal aspect of their heads, in the midline between their ears, and another one attached to their sacral tuberosities. Next, a gyroscope was placed on the dorsal aspect of the 
animals' right forelimb quarter. The placement of the inertial sensors is shown in figure 1.

Data collection was carried out while animals were pulled a straight line at trot for 25-30 meters (round trip) in order to enable at least 25 steps. This procedure was the baseline assessment used to identify the presence, or absence, of lameness, as well as its intensity.

Flexion tests were sequentially performed by the same person in all horses starting with the sound fore or hind limb. A pre-flexion evaluation using 8 to 12 steps was collected before flexion tests to compare flexion results. A sequence using distal forelimb flexion for 30 seconds and total hindlimb flexion for 60 seconds was utilized to optimize the lameness exam based on the high prevalence described of foot lesions $(68.6 \%)$ in the forelimb and tarsus and related structures lesions $(78.8 \%)$ in the hind limbs of Criolo horses (ABREU et al., 2011). A new baseline evaluation was collected to all horses after flexion tests as previously described.

Collected data were analyzed at real time in a specific software (KEEGAN et al., 2011). The analysis was based on the following measurements: HDmax of forelimbs (mean and standard deviation) difference between the highest point of animals' head after the right forelimb support and the highest point of their head after left forelimb support; HDmin of forelimbs (mean and standard deviation) - difference between the lowest point of animals' head during right forelimb support and the lowest point of their head during left forelimb support. HDmax and HDmin were used to calculate the Vector Sum (VS), which measures lameness intensity, based on the formula below:

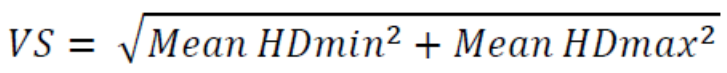

The lameness observed in the forelimbs corresponded to assessment results showing VS greater than $8.5 \mathrm{~mm}$ and at least one HDmax value or one HDmin value above $6 \mathrm{~mm}$ and their respective standard deviation was lower than their mean (EQUINOSIS, 2019).

The assessment of hindlimbs consisted in calculating the following variables: PDmax of hindlimbs (mean and standard deviation) - difference between the highest point of the animals' pelvis

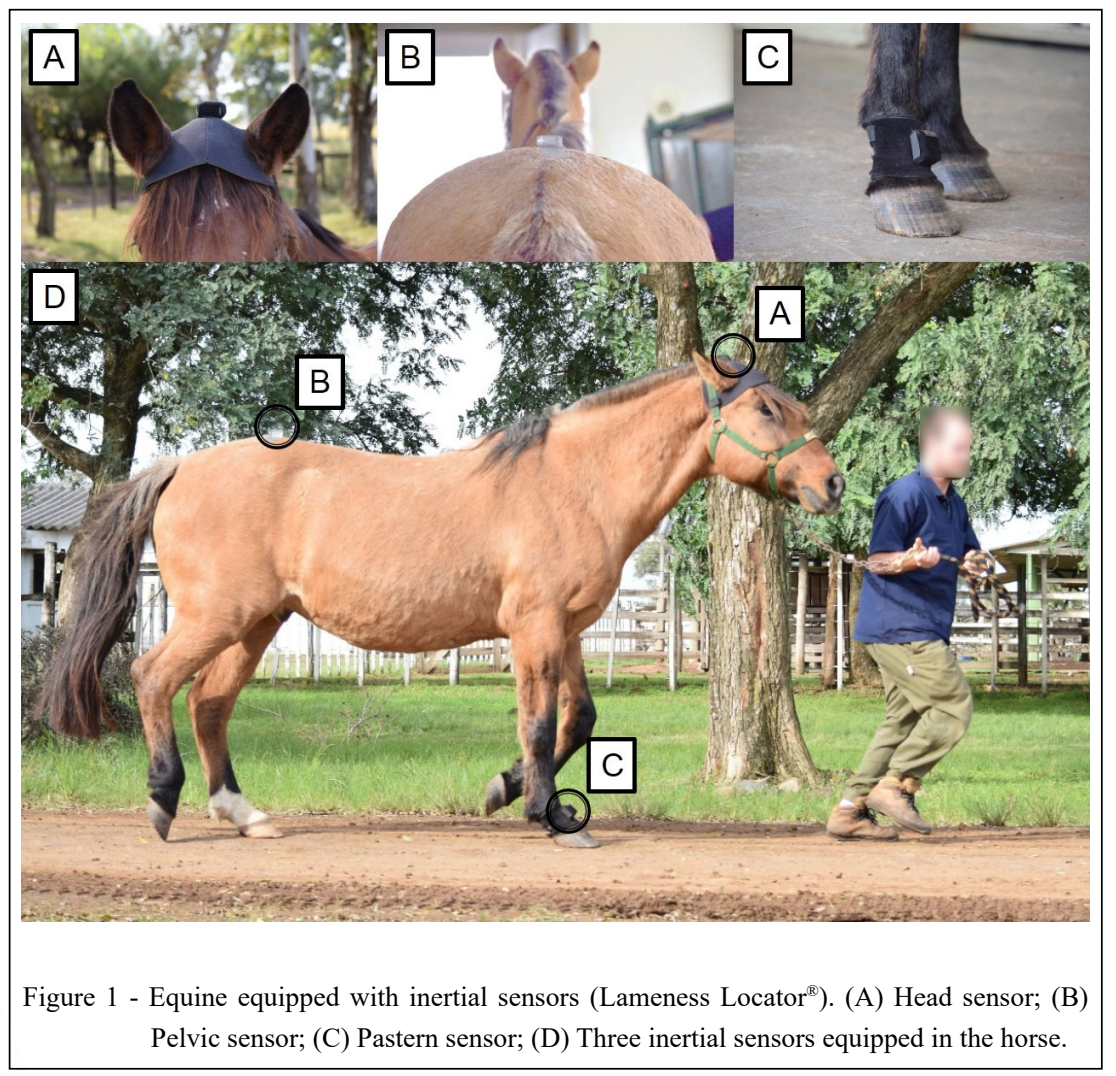

Ciência Rural, v.52, n.5, 2022. 
after the right hindlimb support and the highest point of their pelvis after the left hindlimb support; PDmin of hindlimbs (mean and standard deviation) - difference between the lowest point of the animals' pelvis during right hindlimb support and the lowest point of their pelvis during left hindlimb support. The lameness observed in the hindlimbs corresponded to assessment results showing at least one PDmax value or one PDmin value above $3 \mathrm{~mm}$ and their respective standard deviation lower than their mean (EQUINOSIS, 2019).

Lameness intensity (mild, moderate or severe) and type (push-off or impact) were measured based on information generated in the assessment software, and interpreted according to the user manual (EQUINOSIS, 2019).

The comparison among means recorded for variables VS, HDmax, HDmin, PDmax and PDmin, which were measured by the inertial sensors in initial baseline and post-flexion assessments, was carried out through Wilcoxon statistical test $(\mathrm{P}<0.05)$ for non-parametric data analysis. The types of floors were evaluated by the Kruscall Wallis non-parametric test $(\mathrm{P}<0.05)$.

\section{RESULTS AND DISCUSSION}

All animals presented physiological results in the overall clinical examination and were subjected to objective lameness assessment. The table 1 shows data of all 21 assessed animals.

The objective lameness assessment of equine-assisted therapy horses has shown that $90.1 \%$ $(19 / 21)$ of animals presented some lameness degree - lameness was more prevalent in hindlimbs than in forelimbs (Figure 2). Most animals (61.9\%) were assessed on hard floor (concrete or asphalt), whereas the remaining ones were assessed on soft floor (sand or grass). All six equine-assisted therapy centers evaluated presented animals with lameness; only centers $\mathrm{C}$ and $\mathrm{F}$ had one animal who did not have lameness. As the evaluation occurred at the trot, this lameness may not interfere with the horse's wellbeing, given that the practices occur at a walk.

Mild lameness intensity was mostly prevalent in animals' hindlimbs (47.6\%) and forelimbs (38.1\%) (Figure 3). Push-off lameness was observed in $71.4 \%$ of the assessed animals, impact lameness was observed in $66.7 \%$ of them, whereas $38.1 \%$ of animals presented push-off and impact lameness.

Lameness in the Left Hindlimb (LHL) was observed in $14.3 \%$ (3/21) of horses; two animals had impact lameness and one had push-off lameness.
On the other hand, lameness in the Right Forelimb (RFL) was observed in $38.1 \%(8 / 21)$ of the assessed horses; four animals had push-off lameness and four had impact lameness (Figure 4). Lameness in the Left Hindlimb (LHL) was observed in $57.1 \%(12 / 21)$ of the horses; five animals had push-off lameness, three had impact lameness and four had impact and pushoff lameness. Lameness in the Right Forelimb (RFL) was observed in $9.5 \%$ (2/21) of the horses; one animal had impact lameness and one had impact and pushoff lameness (Figure 5). As shown in figure 6, it is possible to observe that the flexion tests did not cause a significant difference in the parameters used to identify the phase of lameness, both for hindlimbs (Push-off (PDmax) and Impact (PDmin) and for forelimbs, whereas for forelimbs the height of HDmax and HDmin of the head are closely related and, although measured separately, should be considered together (Vector Sum) in determining the side and phase of lameness (impact, mid-stance or push-off).

The variables VS, HDmax, PDmax and PDmin did not show significant difference between initial baseline and post-flexion assessments (Figure 6). HDmin was significant, but in isolation it is not used as a parameter for the interpretation of lameness. To identify lameness, Vector Sum is used, which allows a more reliable interpretation of the data, but this did not show statistical difference. The test flexion is used to exacerbate lameness or discovery of hidden lameness, where the limb is flexed, not differentiating the location of the pain, intensifying the pain if present in the whole limb (ROSS, 2011a). Also, according to Roos (2011a) flexion tests can cause an induced lameness that may not have any clinical relevance for basal lameness, observed during the initial movement. Complementing the author still says that these tests are not sensitive or specific and often result in false-positive and false-negative results.

Studies focused on investigating lameness prevalence in equine-assisted therapy animals remain scarce in the literature. The current research is based on the objective lameness assessment of these horses.

The objective lameness assessment method has gained importance in recent years. Studies have shown that the subjective assessment of mild lameness is unreliable, since evaluators are vulnerable to a range of biases capable of negatively affecting lameness identification and accurate location, with emphasis on the experience level of each observer (McCRACKEN et al., 2012). As described by KEEGAN et al. (2012) the results obtained from the analysis by inertial sensors 
Table 1 - Lameness data generated in the Lameness Locator, site and animals' features - Rio Grande do Sul State, Brazil.

\begin{tabular}{|c|c|c|c|c|c|c|}
\hline \multirow[t]{2}{*}{ Animal/Sex/Origin } & \multicolumn{2}{|c|}{----------------Forelimb------------- } & \multicolumn{2}{|c|}{--------------------'Hindlimb------------------ } & \multirow[t]{2}{*}{ Floor type } & \multirow[t]{2}{*}{ Group } \\
\hline & Left & Right & Left & Right & & \\
\hline 1/ F/ Donation & - & - & $\begin{array}{l}\text { Mild push-off } \\
\text { lameness }\end{array}$ & $\begin{array}{l}\text { Mild impact } \\
\text { lameness }\end{array}$ & Sand & A \\
\hline 2/ M/ Donation & $\begin{array}{l}\text { Mild push-off } \\
\text { lameness }\end{array}$ & - & $\begin{array}{l}\text { Mild impact } \\
\text { lameness }\end{array}$ & - & Sand & A \\
\hline 3/ F/ Donation & - & - & $\begin{array}{l}\text { Mild push-off } \\
\text { lameness }\end{array}$ & - & Sand & A \\
\hline 4 / F /Donation & - & $\begin{array}{l}\text { Mild push-off } \\
\text { lameness }\end{array}$ & $\begin{array}{l}\text { Mild push-off } \\
\text { lameness }\end{array}$ & - & Sand & A \\
\hline $5 / \mathrm{F} /$ Donation & $\begin{array}{l}\text { Mild impact } \\
\text { lameness }\end{array}$ & - & $\begin{array}{l}\text { Mild push-off and } \\
\text { impact lameness }\end{array}$ & - & Grass & B \\
\hline $\begin{array}{l}6 / \mathrm{M} / \mathrm{B} \text { orn at the } \\
\text { center }\end{array}$ & - & - & $\begin{array}{l}\text { Moderate push-off } \\
\text { lameness }\end{array}$ & - & Grass & $\mathrm{B}$ \\
\hline $\begin{array}{l}7 / F / \text { Born at the } \\
\text { center }\end{array}$ & - & $\begin{array}{l}\text { Mild push-off } \\
\text { lameness }\end{array}$ & - & - & Grass & B \\
\hline 8 / F / Donation & - & - & $\begin{array}{l}\text { Moderate push-off } \\
\text { and impact lameness }\end{array}$ & - & Grass & $\mathrm{B}$ \\
\hline 9 / M /Donation & - & - & - & - & Asphalt & $\mathrm{C}$ \\
\hline 10 / F / Donation & - & - & $\begin{array}{l}\text { Moderate push-off } \\
\text { and impact lameness }\end{array}$ & - & Asphalt & $\mathrm{C}$ \\
\hline 11 / M / Donation & - & - & $\begin{array}{l}\text { Mild impact } \\
\text { lameness }\end{array}$ & - & Asphalt & $\mathrm{C}$ \\
\hline 12 / M / Donation & - & $\begin{array}{l}\text { Mild impact } \\
\text { lameness }\end{array}$ & - & - & Asphalt & $\mathrm{C}$ \\
\hline 13 / F / Donation & - & $\begin{array}{l}\text { Moderate } \\
\text { impact } \\
\text { lameness }\end{array}$ & - & - & Concrete & $\mathrm{D}$ \\
\hline 14 / M / Donation & - & $\begin{array}{l}\text { Moderate } \\
\text { impact } \\
\text { lameness }\end{array}$ & - & $\begin{array}{l}\text { Moderate push-off } \\
\text { and impact lameness }\end{array}$ & Concrete & $\mathrm{D}$ \\
\hline 15 / F / Donation & - & $\begin{array}{l}\text { Mild push-off } \\
\text { lameness }\end{array}$ & - & - & Concrete & $\mathrm{D}$ \\
\hline 16 / F / Donation & - & $\begin{array}{l}\text { Mild push-off } \\
\text { lameness }\end{array}$ & - & - & Concrete & $\mathrm{D}$ \\
\hline 17 / M / Donation & - & - & $\begin{array}{l}\text { Mild push-off and } \\
\text { impact lameness }\end{array}$ & - & Concrete & $\mathrm{E}$ \\
\hline 18 / F / Donation & - & - & $\begin{array}{l}\text { Mild impact } \\
\text { lameness }\end{array}$ & - & Concrete & $\mathrm{E}$ \\
\hline 19 / M / Donation & $\begin{array}{l}\text { Moderate impact } \\
\text { lameness }\end{array}$ & - & $\begin{array}{l}\text { Mild push-off } \\
\text { lameness }\end{array}$ & - & Concrete & $\mathrm{E}$ \\
\hline 20 / F/ Donation & - & $\begin{array}{l}\text { Mild impact } \\
\text { lameness }\end{array}$ & - & - & Asphalt & $\mathrm{F}^{*}$ \\
\hline 21 / M/ Donation & - & - & - & - & Asphalt & $\mathrm{F}^{*}$ \\
\hline
\end{tabular}

A= São Gabriel; $B=$ Santa Maria; $C=$ Santo Ângelo; $D=$ São Luiz Gonzaga; $E=$ Itaqui, $F^{*}=$ Santa Maria; $F=$ female; $M=$ male. Source: prepared by the author, 2019 . 


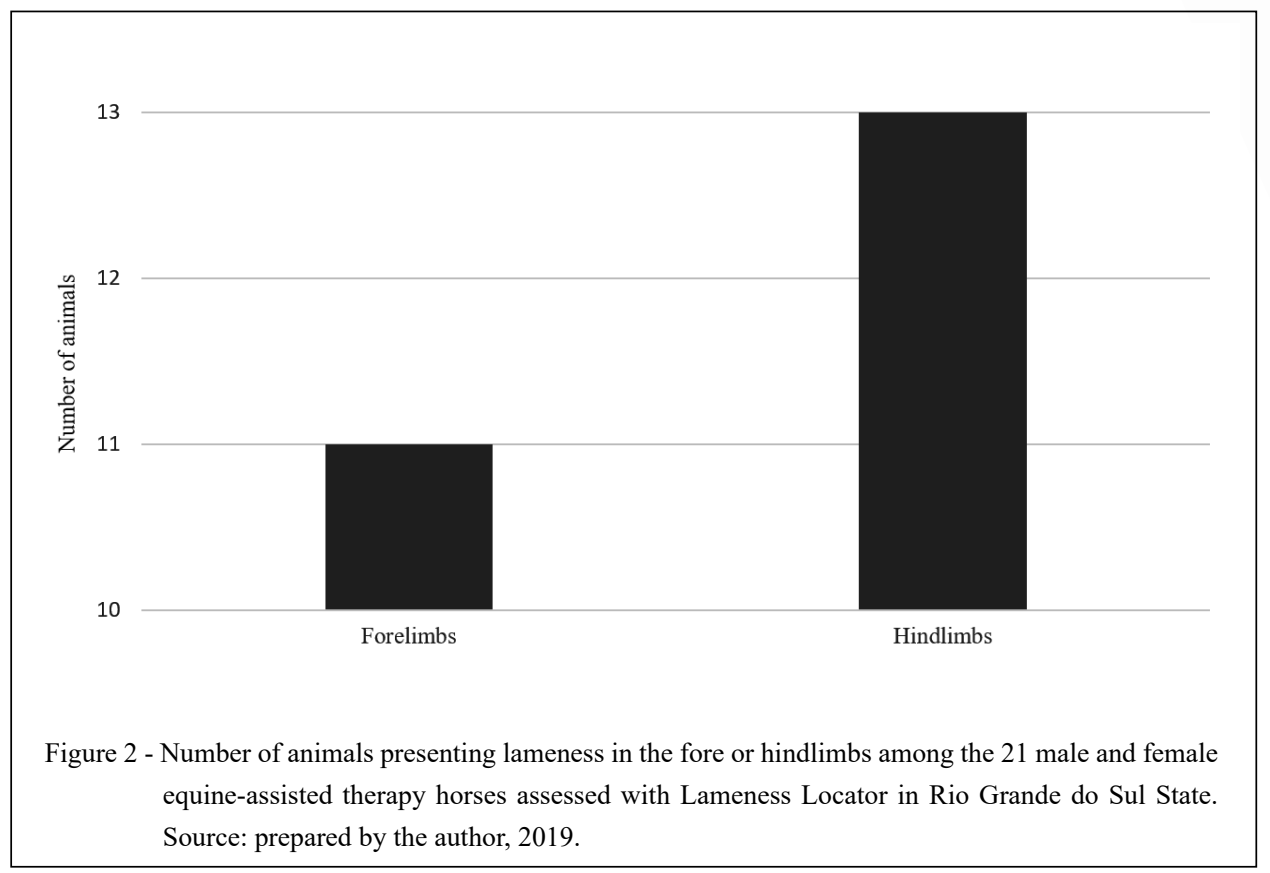

in lameness involving both chest members have an adequate sensitivity for their use. The asymmetry of head and pelvis movement analyzed by the inertial sensor system for the assessment and detection of lameness in horses trotting in a straight line was reliable for clinical use (KEEGAN et al., 2011).
The current study recorded high lameness prevalence, since more than $90 \%$ of assessed animals have shown some lameness intensity degree. Although the present study did not perform lesion diagnosis, the high incidence of lameness was a strong indication that the assessed animals

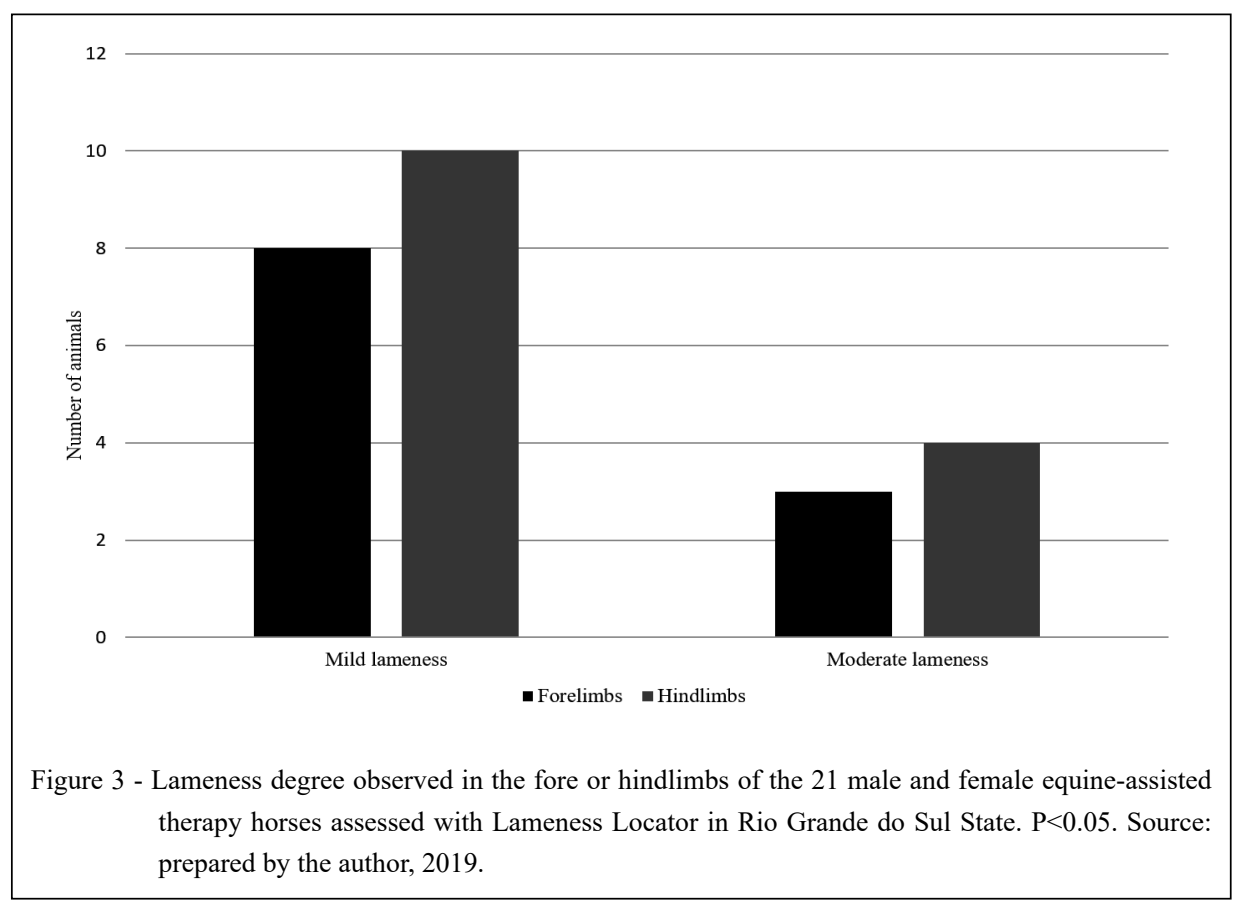

Ciência Rural, v.52, n.5, 2022. 


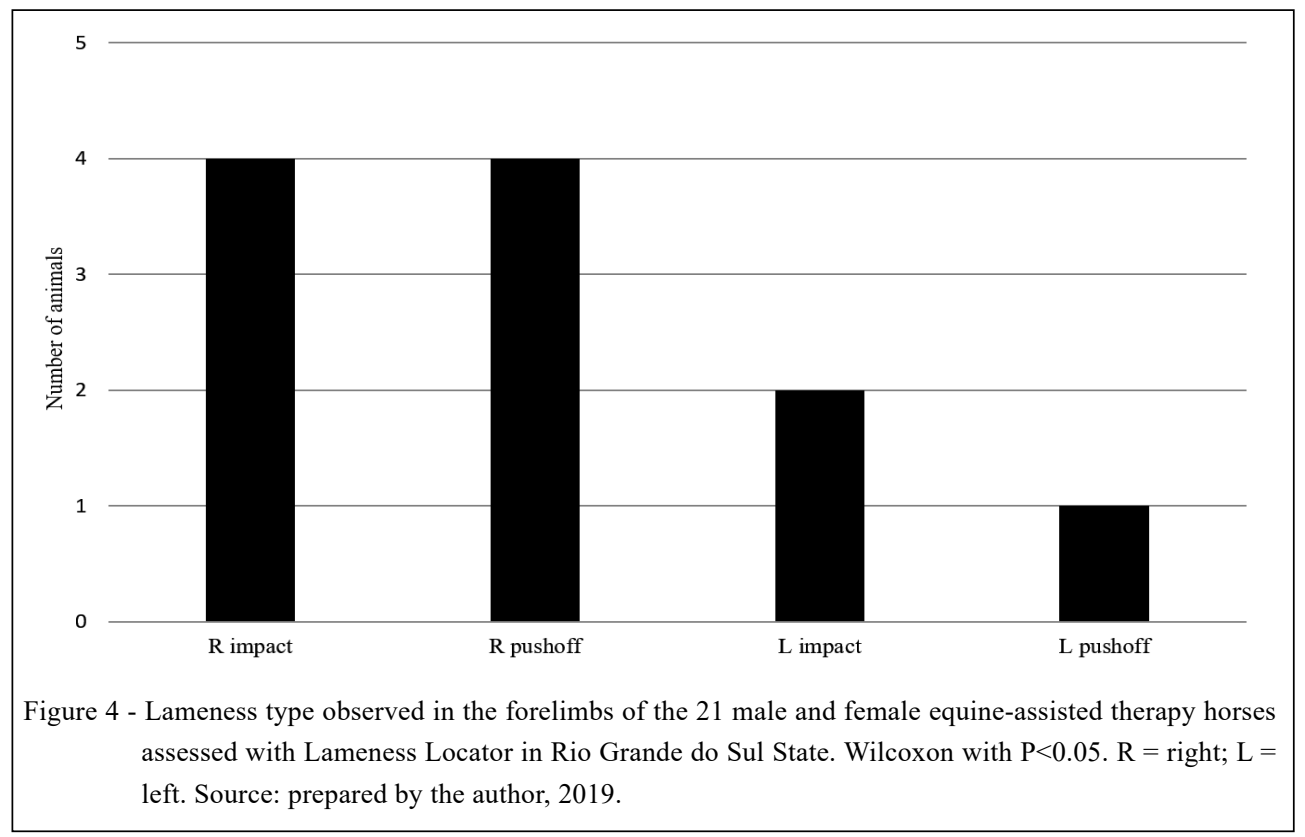

presented some change in the skeletal muscle system, since lameness is nothing more than a clinical sign or manifestation of structural or functional changes in one, or more, horse limbs (BAXTER, 2011b). SILVA et al. (2012) have evaluated the clinical records of 17 animals used for equine-assisted therapy in Uruguaiana County and found that $23.4 \%$ of them had locomotor system-related issues; this percentage was much lower than the one observed in the current study.
According to BAXTER (2011b), lameness is more often found in the forelimbs than in the hindlimbs, since $60 \%$ to $65 \%$ of animals' body weight is supported by their forelimbs. The current study showed a larger number of animals with lameness in the hindlimbs; this outcome corroborates the study by ABREU et al. (2011), who found 59.2\% (118/201) of the assessed Criolo breed animals with lameness in the hindlimb. The high lameness prevalence observed in

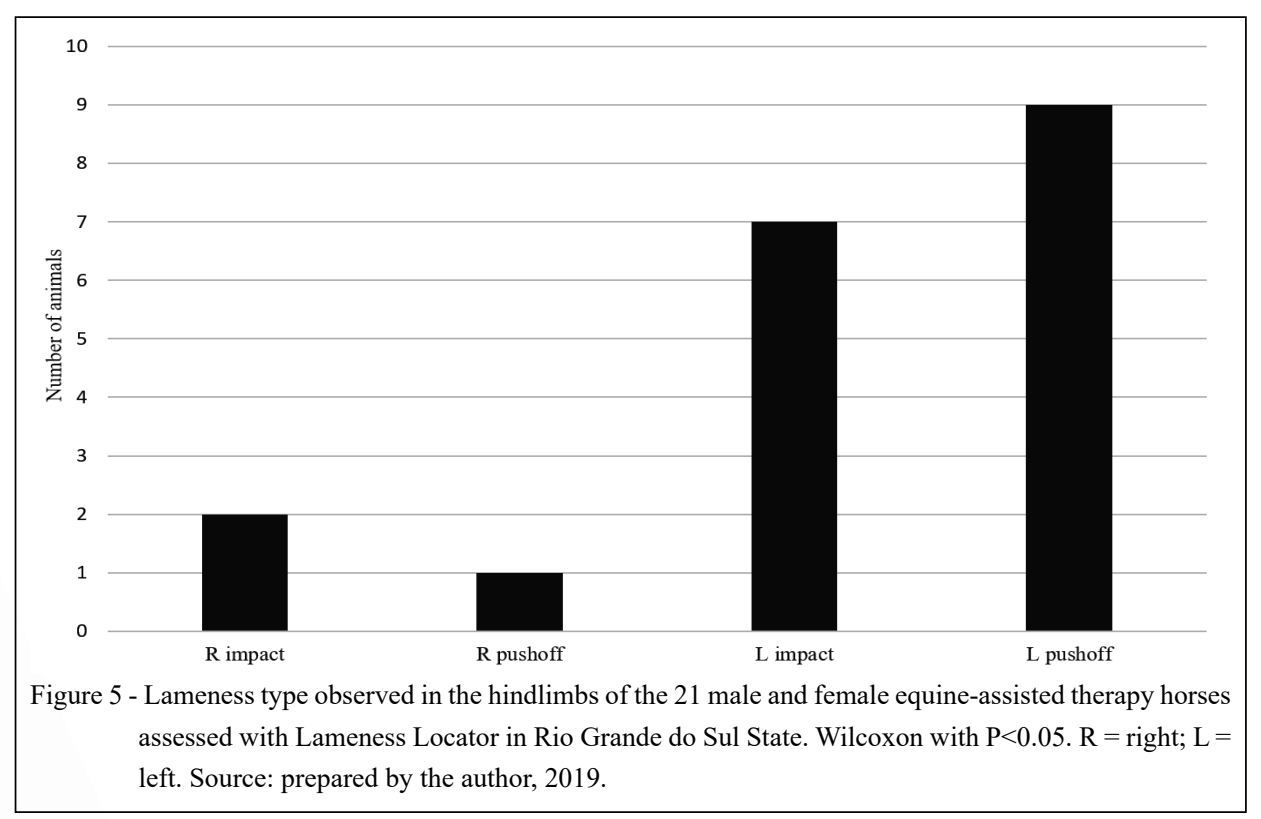

Ciência Rural, v.52, n.5, 2022. 


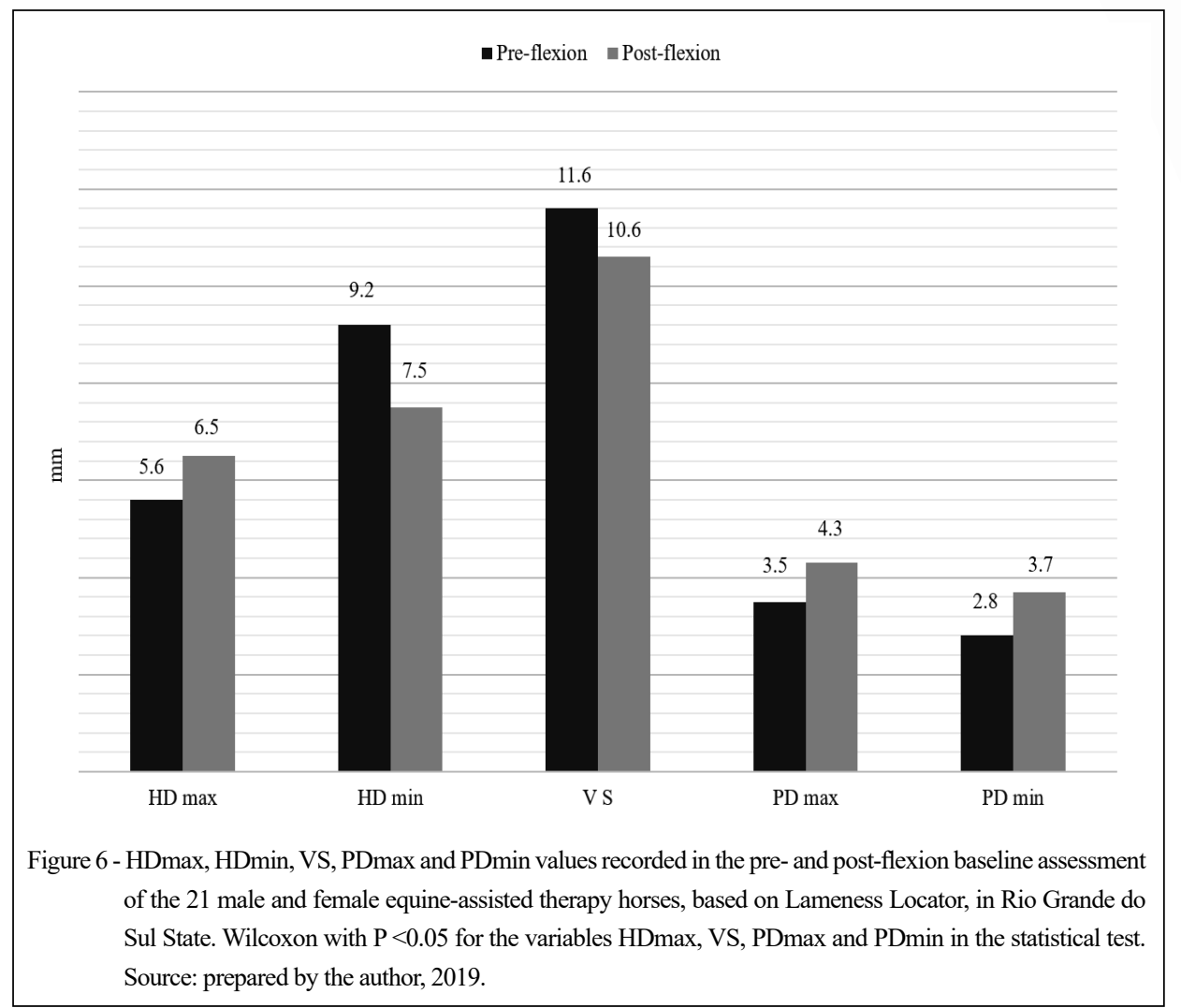

the hindlimbs may be associated with animals' breed and use prior to the equine-assisted therapy, since most animals used for this therapy belonged to Criolo breed and were donated by previous owners. In other words, these animals may have been previously used for field work or even for sports; therefore, they presented some degree of locomotor system impairment at pelvic level.

It is essential selecting the right location to perform the examination, since some lameness types can be exacerbated, or weakened, depending on the floor type. The animals should be preferably examined on a flat, smooth and non-slippery surface, since slippery floors can make them take short strides and lead to misinterpretation of lameness data (BAXTER, 2011b; ROSS, 2011b). The main importance of selecting the ideal floor type lies on the exacerbation of some lameness types that are linked to the floor type where animals are examined on. Hard floors can lead to maximum concussion, which may exacerbate subtle lameness and predispose animals to present impact injuries, mainly in the osteoarticular structures (ROSS, 2011b).

However, AZEVEDO et al. (2015) have used inertial sensors to assess horses and they did not find difference in variables such as maximum and minimum height of head and pelvis in animals examined on three different floor types (concrete, sand and grass), or difference between floor type (hard versus soft) and lameness type (impact versus push-off). Thus, analyses were performed by taking into consideration floor availability in each equestrian center. It was verified by the Kruscall Wallis nonparametric test, there was no significant difference $(\mathrm{P}$ $<0.05$ ) between the floors.

The current study recorded higher prevalence of push-off lameness $(71.4 \%)$, which is often seen when the limb is suspended. Moreover, push-off lameness may indicate changes in muscles, tendons, tendon sheaths and bursae. Impact lameness was the second most prevalent $(66.7 \%)$ type. It often happens when the limb touches the ground or when it supports the animals' body weight; it may be associated with injuries in bones, joints and other support structures (BAXTER, 2011b).

Pain in one limb can lead to uneven weight distribution in another limb or limbs; this process can generate lameness in a previously healthy limb - it is called compensatory lameness (BAXTER, 2011b). 
Compensatory lameness develops in the forelimb located at the same side of the hindlimb presenting primary lameness; it may have happened in horses $2,5,14$ and 19 . If the forelimb is the primary issue, compensatory lameness often develops in the contralateral hindlimb - it may have happened in horse 4. Anesthetic nerve blocks can be performed to confirm these suspicions, since by blocking the primary cause it is possible to decrease or even eliminate compensatory lameness (BAXTER, 2011a).

The limitations of this study include the variability of floors between the riding therapy centers to carry out the assessments and the lameness locations not being confirmed by anesthetic blocks. This was not done due to lack of funds.

All riding therapy centers received a report that contained the animal's identification, information on the lameness test and the result of the assessment. This report had the objective that the therapy centers would make an improvement through trimming, shoeing, rest and later evaluation of the evolution of this lameness.

In this study, 19/21 of horses assessed in the current study presented some lameness degree, and it justifies the need of evaluating the locomotor system of horses used for equine-assisted therapy. However, since equine-assisted therapy sessions are based on walk gait and the assessment performed in the current study was based on trot gait, it is essential conducting further research on this subject in order to investigate the association between lameness incidence in equine-assisted therapy horses and the evolution of patients under this therapy. Assumingly, the subtle lameness intensity observed at trot gait may not be enough to cause changes in walk gait; consequently, it does not impair impulse transmission to therapy patients.

\section{CONCLUSION}

The objective lameness assessment based on wireless inertial sensors (Lameness Locator $^{\mathbb{R}}$ ) has shown high lameness prevalence in the assessed animals; mild lameness was the most prevalent. The current study emphasized the importance of examining animals' locomotor system, as well as of hiring a veterinary doctor to monitor these animals in order to assure their well-being and the quality of the equine-assisted therapy.

Future studies focused on evaluating the possible correlation between lameness improvement and patients' clinical evolution should be conducted to provide relevant information about the equineassisted therapy scenario.

\section{ACKNOWLEDGMENTS}

The authors are grateful to all equine-assisted therapy centers, for allowing their horses to be assessed; to Universidade Federal de Santa Maria for making their equipment available; and to Georgia Camargo Góss and Débora da Cruz Payão Pellegrini for performing the statistical analysis.

\section{BIOETHICS AND BIOSSECURITY COMMITTEE APPROVAL}

The study was approved by the Ethics Committee on Animal Use (CEUA - Comitê de Ética no Uso de Animais) of Universidade Federal do Pampa (UNIPAMPA), under protocol n. 020/2019.

\section{CONFLICTS OF INTEREST}

The authors declare no conflict of interest.

\section{AUTHORS' CONTRIBUTIONS}

The authors also contributed to the manuscript. MSA equipped all horses with the software sensors. PMT performed the clinical evaluation and specific examination of the locomotor system of all horses. Everyone participated and helped with the collections and analyzes.

\section{REFERENCES}

ABREU, H.C. et al. Lameness in athletic Criollo horses. Ciência Rural, Santa Maria, v.41, n.12, p.2114-2119, dec. 2011. Available from: <http://dx.doi.org/10.1590/S0103-84782011001200013>. Accessed:Nov. 18,2019.doi: 10.1590/S0103-84782011001200013.

ANDRADE, G.P.S.; CUNHA, M.M. The importance of hippotherapy as a tool to support the teaching and learning process of children served in this therapeutic modality. Revista Eventos Pedagógicos, v.5, n.2, p.132-142, 2014.

AZEVEDO, M.S. et al. Impact or push-off lameness presentation is not altered by the type of track surface where horses are trotted. Arquivo Brasileiro de Medicina Veterinária e Zootecnia, v. 67, n.6, p.1475-1482, 2015. Available from: $<$ http://dx.doi.org/10.1590/16784162-8454>. Accessed: Oct. 19, 2019. doi: 10.1590/1678-4162-8454.

BARREY, E. Gaits and interlimb coordination. In: BACK, W.; CLAYTON, H. Equine locomotion. 2.ed. Ed. Saunders Elsevier, 2013. Cap.5, p.85-97.

BAXTER, G.M. Assessment of the lame horse. In: BAXTER, G.M. Manual of equine lameness. Ed. Wiley Blackwell, 2011a. Cap. 3, p. 208-399.

BAXTER, G.M. Fundamentals of lameness diagnosis. In: BAXTER, G.M. Manual of equine lameness. Ed. Wiley Blackwell, 2011b. Cap. 2, p. 163-207.

EQUINOSIS, LLC. User Manual Lameness Locator Touch 1.0 Biomechanical Care System, 2019.

HAMEURY, L. et al. Equine-assisted therapy and autismo. Annales Médico-Psychologiques, v.168, p.655-659, 2010. Available from: 
$<$ https://doi.org/10.1016/j.amp.2009.12.019>. Accessed: Jul. 20, 2020. doi: 10.1016/j.amp.2009.12.019.

KEEGAN, K.G. et al. Assessment of repeatability of a wireless, inertial sensor-based lameness evaluation system for horses. American Journal of Veterinary Research, v.72, n.9, p.1156-1163, sept. 2011. Available from: $<$ https://doi.org/10.2460/ajvr.72.9.1156>. Accessed: Jul. 21, 2020. doi: 10.2460/ajvr.72.9.1156.

KEEGAN, K.G. et al. Comparison of an inertial sensor system with a stationary force plate for evaluation of horses with bilateral forelimb lameness. American Journal of Veterinary Research, v.73, n.3, p.368-74, mar. 2012. Available from: <https://doi. org/10.2460/ajvr.73.3.368>. Accessed: Jul. 22, 2020. doi: 10.2460/ ajvr.73.3.368.

LOJEK, J. et al. Conformation analysis of horses used in equineassisted activities at Polish hippotherapeutic centers. Acta Scientiarum Polonorum Zootechnica, v.14, n.2, p.121-134, 2015.

LEMKE, D. et al. Perceptions of Equine-Assisted Activities and Therapies by Parents and Children With Spinal Muscular Atrophy. Pediatric Physical Therapy, v. 26, p. 237-244, 2014. Available from: <https://doi.org/10.1097/PEP.0000000000000027>. Accessed: Jul. 20, 2020. doi: 10.1097/PEP.0000000000000027.

McCRACKEN M.J. et al. Comparison of an inertial sensor system of lameness quantification with subjective lameness evaluation. Equine Veterinary Journal, v.44, n.6, p.652656, nov. 2012. Available from: <https://doi.org/10.1111 /j.2042-3306.2012.00571.x>. Accessed: Aug. 15, 2019. doi: 10.1111/j.2042-3306.2012.00571.x.

PFEIFER, L. T. O. et al. Equoterapia. A influência da variação do peso na frequência do passo do cavalo. Ensaios e Ciência Ciências Biológicas, Agrárias e da Saúde, v.16, n.3, p.3948, 2012. Available from: <http://www.redalyc.org/articulo. oa?id=26029237004>. Accessed: Aug. 17, 2021.

PEREIRA, E. L. et al. Equine-assisted therapy, health and sports: figurations of the practice in the state of Rio Grande do Sul, 1970-
2000. História, Ciências, Saúde Manguinhos, v.27, n.3, p.879897, 2020. Available from: <http://dx.doi.org/10.1590/S010459702020000400010>. Accessed: Aug. 17, 2021. doi: 10.1590/ S0104-59702020000400010.

ROSS, M.W. Manipulation. In: ROSS, M. W. \& DYSON, S. J. Diagnosis and management of lameness in the horse. 2.ed. Philadelphia : Saunders, 2011a. Cap. 8, p.80-88.

ROSS, M.W. Movement. In: ROSS, M. W. \& DYSON, S. J. Diagnosis and management of lameness in the horse. 2.ed. Philadelphia : Saunders, 2011b. Cap.7, p.64-80.

SILVA, M.N.G. et al. A review of hippoterapy horse diseases from 2006 to 2010 in Uruguaiana-RS. Revista brasileira de Ciência Veterinária, Niterói, v.19, n.3, p.139-143, 2012. Available from: $<$ http://dx.doi.org/10.4322/rbcv.2014.109>. Accessed: Nov. 20, 2019. doi: $10.4322 /$ rbcv.2014.109.

SILVEIRA, M.M.; WIBELINGER, L.M. Reeducation of posture with hippotheraphy. Revista Neurociência, v.19, n.3, p.519524, 2011. Available from: <https://doi.org/10.34024/rnc.2011. v19.8353>. Accessed: Nov. 20, 2019. doi: 10.34024/rnc.2011. v19.8353

TOIGO, T. et al. The use of hippotherapy as therapeutic resource to improve the static balance in elderly individuals. Revista Brasileira de Geriatria e Gerontologia, Rio de Janeiro, v.11, n.3, p.391-403, 2008. Available from: $<$ http://dx.doi.org/10.1590/18099823.2008.11038>. Accessed: Dec. 19, 2019. doi: 10.1590/18099823.2008.11038

UZUN, L.L.A. Equoterapia: Aplicação em distúrbio do equilíbrio. São Paulo, SP: Vetor, 2005.

WHITE-LEWIS, S. et al. Equine-assisted therapy intervention studies targeting physical symptoms in adults: A systematic review. Applied Nursing Research, v. 38, p. 9-21, dec. 2017. Available from: <https://doi.org/10.1016/j. apnr.2017.08.002>. Accessed: Jul. 20, 2020. doi: 10.1016/j. apnr.2017.08.002. 